\title{
TOLERANSI DAN KERUKUNAN UMAT BERAGAMA DI MASYARAKAT RANDUACIR
}

\author{
Rasimin \\ Mahasiswa Program Doktoral UPI Bandung \\ rasimin75@gmail.com
}

\begin{abstract}
This research used the qualitative approach, i.e. the research that generates descriptive data in the form of the written word or people speaking or behavior that can be observed. The results of this research show that pluralisme and nonviolence in religion at Randuacir Argomulyo Salatiga namely: (a) through the efforts of internal dialogue and religious interfaith, this requires a change of perspective and how to act regarding to the presence of different cultures and religions. The point to understand the process of a dialogue is based on the willingness to open up in encountering authenticity, and on a whim to appear critical and objective interreligious dialogue that departs from the obscurity of the concept and perception that in the end it will only bore the forum because they are blasphemous, adjudicate, and justify his group.
\end{abstract}

Keyword: Communication, Harmony, Religion

\begin{abstract}
Abstrak
Penelitian ini menggunakan pendekatan kualitatif yaitu penelitian yang menggunakan data deskriptif yang berbentuk tulisan, perkataan, atau tingkah laku yang dapat diukur. Hasil dari penelitian ini menunjukkan bahwa pluralism dan anti kekerasan dalam beragama di desa Randuacir Argomulyo Salatiga berupa melalui upaya dialog internal dan antar beragama membutuhkan perubahan perpektif dan dan bagaimana bersikap karena karena adanya perbedaan budaya dan agama. Inti dalam memahami proses dialog didasarkan pada keinginan untuk membuka diri dalam menyikapi kebenaran dan sikap untuk mewujudkan dialog antar agama yang kritis dan objektif yang berawal dari ketidakjelasan konsep dan persepsi yang pada akhirnya hanya menjenuhkan forum karena mereka hanya menghujat, menghakimi, dan membenarkan kelompok mereka.
\end{abstract}

Kata Kunci: Kumunikasi, Toleransi, Agama 
INJECT: Interdisciplinary Journal of Communication, Vol.1, No.1, Juni 2016: h. 99-118

\section{Pendahuluan}

Masyarakat Indonesia yang plural, dengan ragam budaya, suku, etnis dan agama serta idiologi merupakan kekayaan tersendiri. Oleh karena itu, keragaman agama, etnis, idiologi ataupun budaya membutuhkan sikap arif dan kedewasaan berpikir dari berbagai lapisan masyarakat, tanpa memandang agama, warna kulit, status sosial dan etnis. Tanpa ada sikap saling curiga dan berprasangka buruk terhadap kelompok lain, kita sebagai bangsa sudah terlanjur majemuk dan konsekuensinya adalah adanya penghormatan atas pluralitas masyarakat itu.

Pada konteks yang lebih kecil Kota Salatiga yang notabene masyarakatnya beragama (Islam, Kristen, Katolik, Hindu, Budha). Keberagaman agama ini justru berujung pada hilangnya penghargaan terhadap agama lain, atau bahkan madzhab lain bagi yang seagama. Sehingga yang terjadi adalah, ekperientasi keagamaan dengan berbagai bentuknya, seperti kekerasan atas nama agama, dan radikalisme artikulasi agama ke ruang publik. Munculnya beberapa kasus seperti peristiwa 'Ngawi Kelabu', tepatnya hari Kamis, 29 November 2001. Terorisme di Mojokerto, dan bom Bali yang menewaskan lebih dari 202 nyawa. Kasuskasus ini dilandasi atas nama agama pula. Jika keragaman tersebut tidak mampu dimanage dengan baik, maka dapat menjadi sumber konflik social dengan sensivitas yang tinggi.

Randuacir adalah salah satu desa di Kecamatan Argomulyo Kota Salatiga yang plural sangat mencerminkan gaya hidup dan keberagaman. Dari sini bisa dilihat bahwa kesadaran masyarakat terhadap perbedaan masih sangatlah kurang, harus diakui bahwa perbedaan agama memang ada, tetapi perbedaan itu bukanlah hakiki, karena yang hakiki adalah persaudaraan di antara umat beragama itu sendiri. Indonesia dikenal sebagai masyarakat majemuk atau pluralistic society. Hal ini dapat dilihat dari realitas sosial yang ada, kemajemukan ini juga dapat dibuktikan melalui semboyan Negara Republik Indonesia, yakni 'Bhineka Tunggal 
Ika'. Sebagai Negara yang plural, hendaknya warga Indonesia dapat menyadari dengan adanya perbedaan tersebut.

\section{Permasalahan}

Fokus masalah ini dapat diuraikan sebagai berikut; (a) Bagaimana pandangan masyarakat tentang nilai-nilai pluralisme di Randuacir Kecamatan Argomulyo Kota Salatiga? (b) Bagaimana pola kerukunan antar umat beragama di Randuacir Kecamatan Argomulyo Kota Salatiga? (c) Bagaimana bentuk pluralisme dan kerukunan umat beragama masyarakat Randuacir Kecamatan Argomulyo Kota Salatiga?

\section{Nilai-Nilai Pluralisme}

Pluralisme berasal dari kata plural dan isme, plural yang berarti banyak (jamak), sedangkan isme berartipaham. Jadipluralismee adalah suatu paham atau teori yang menganggap bahwa realitas itu terdiri dari banyak substansi (Dahlan, 1994:604).

Plural pada intinya menunjukkan lebih dari satu dan isme adalah sesuatu yang berhubungan dengan paham atau aliran. Dengan demikian pluralisme adalah paham atau sikap terhadap keadaan majemuk atau banyak dalam segala hal diantaranya sosial, budaya, politik dan agama (Chomsah, 2012:26). Pluralisme agama bisa dipahami dalam tiga sudut pandang; Pertama, sosial yaitu semua agama berhak untuk ada dan hidup, artinya semua umat beragama sama-sama belajar untuk toleran, dan menghormati iman atau kepercayaan dari setiap penganut agama. Kedua, etika atau moral yaitu semua umat beragama memandang bahwa moral atau etika dari masing-masing agama bersifat relatif dan sah apabila umat beragama menganut pluralisme agama dalam nuansa etis, maka didorong untuk tidak menghakimi penganut agama lain. Ketiga, teologi filisofis yaitu agama-agama pada hakekatnya setara, sama-sama benar dan sama menyelamatkan artinya semua agama menuju pada Ketuhanan Yang Maha Esa. 
Oleh sebab itu, yang dimaksud pluralisme agama adalah suatu pemahaman bahwa semua agama mempunyai eksistensi hidup saling berdampingan, saling bekerjasama dan saling berinteraksi antara satu agama dengan agama yang lain. Kemudian dalam ilmu politik melahirkan ilmu tentang kedaulatan, pertama paham teokrasi yakni kedaulatan ditangan Tuhan, kedua paham demokrasi yakni bahwa kedaulatan ditangan masyarakat atau rakyat,ketiga paham teo-demokrasi, teori ini ingin menggabungkan dengan teori di atas. Artinya meskipun pengelolaan di negara adalah ditangan rakyat, namun rakyat tidak boleh lepas dari nilai-nilai ketuhanan (A'la, 2005:79). Dan konsekuensi lebih lanjut dari cara pandang adalah bahwa sumber legitimasi, referensi dan rujukan keagamaan yang memuat pesan-pesan moral kemanusiaan universal harus menjadi dasar prinsip bagi seluruh cara pandang pikiran, konsep, interpretasi, tafsir, perjuangan, kerja dan semua aktifitas manusia di dunia (Muhammad, 2011:14). Jadi pluralisme merupakan cara pandang atau kerangka berpikir untuk menyelaraskan gaya hidup serta menyeimbangkan makna-makna nilai sosial di dalam masyarakat majemuk dan menjunjung tinggi nilai perbedaan agama.

\section{Islam dan Pluralitas Agama}

Al-Quran surat al-Baqarah ayat 148, mengakui masyarakat terdiri berbagai macam komunitas yang memiliki orientasi kehidupan sendirisendiri. Manusia harus menerima kenyataan keragaman budaya dan agama serta memberikan toleransi kepada masing-masing komunitas dalam menjalankan ibadahnya. Oleh karena itu kecurigaan tentang Islam yang anti plural, sangatlah tidak beralasan dari segi idiologis. Bila setiap muslim memahami secara mendalam etika pluralitas yang terdapat dalam al-Quran, tidak perlu lagi ada ketegangan, permusuhan, dan konflik baik internal maupun antaragama selama mereka tidak saling memaksakan.

Pada dasarnya setiap manusia mempunyai kebebasan untuk meyakini agama yang dipilihnya dan beribadat menurut keyakinan tersebut. 
Dalam al-Quran banyak ayat yang berbicara tentang penerimaan petunjuk atau agama Allah. Penerimaan terhadap sebuah keyakinan agama adalah pilihan bebas yang bersifat personal. Barang siapa yang sesat berarti ia menyesatkan dirinya sendiri. Orang yang mendapat petunjuk yang benar tidak akan ada yang menyesatkannya dan orang yang sesat dari jalan yang benar tidak akan ada yang dapat menunjukinya selain Allah. Selain prinsip tidak ada paksaan dalam agama, juga dikenal prinsif 'untuk kalian agama kalian, dan untukku agamaku'. Sungguhpun demikian, manusia diminta untuk menegakan agama fithrah. Fithrah adalah ciptaan dan agama adalah ciptaan Allah. Dua ciptaan dari Maha Pencipta yang sama, yaitu manusia dan agama, tidak mungkin melahirkan kontradiktif. Karena itu, pilihan yang terbaik adalah memilih agama ciptaan Allah. Intinya sama sepanjang sejarah, yang dibawa oleh para Nabi atau Rasul dan disempurnakan dengan kedatangan Nabi Muhammad Saw.

Pluralitas adalah merupakan 'hukum ilahi dan sunnah' ilahiyah yang abadi disemua bidang kehidupan, sehinga pluralitas itu sendiri telah menjadi karakteristik utama semua makhluk Allah terutama manusia dari berbagai macamnya, afialiasinya, dan tingkat prestasi (performance) dalam melaksanakan kewajibannya. Allah berfirman dalam surat al-Hujurat ayat 13 , hai manusia sesungguhnya kami menciptakan kamu dari seorang lakilaki dan perempuan, dan menjadikan kamu berbangsa-bangsa dan bersuku-suku supaya kamu saling kenal mengenal. Sesungguhnya orang yang paling mulia diantara kamu di sisi Allah ialah orang yang paling bertakwa diantara kamu. Sesungguhnya Allah maha mengetahui lagi maha mengenal.

\section{Definisi Pluralisme Agama}

Nurcholis Madjid (dalam Abdul Azis Sachedina, 2009:37) menjelaskan bahwa Pluralisme agama merupakan istilah khas dalam teologi. Dia mengelompokan ada tiga sikap dialog agama yang dapat diambil, 
yaitu; Pertama, sikap ekslusif dalam melihat agama lain sebagai jalan yang salah, yang menyesatkan bagi pengikutnya. Kedua, sikap inklusif yang memandang agama-agama lain adalah bentuk implisit agama kita. Ketiga sikap pluralis yang bisa terekspresi dalam macam-macam rumusan, misalnya agama-agama lain adalah jalan yang sama-sama sah untuk mencapai kebenaran yang sama, agama-agama lain berbicara secara berbeda, tetapi merupakan kebenaran-kebenaran yang sama sah, atau setiap agama mengekspresikan bagian penting sebuah kebenaran.

Sementara Komarudin Hidayat (dalam Jaih Mobarak, 2000:10) mengatakan bahwa sikap pluralisme agama, dipandang sebagai suatu realitas, masing-masing berdiri sejajar sehingga semangat missionaris atau dakwah dianggap tidak relevan, sedangkan universalisme, yakni pandangan bahwa pada dasarnya semua agama satu dan sama. Hanya karena faktor historis-antropologis agama kemudian tampil dalam format plural. Di Indonensia nampaknya umat Islam masih didominasi pandangan ekslusivisme. Di sisi lain MUI mendefinisikan pluralisme agama adalah suatu paham yang mengajarkan bahwa semua agama adalah sama dan karenanya kebenaran setiap agama adalah relatif. Oleh sebab itu, setiap pemeluk agama tidak boleh mengklaim bahwa hanya agamanya saja yang benar sedangkan agama lain salah. Pluralisme juga mengajarkan bahwa semua pemeluk agama akan masuk dan hidup berdampingan di surga. Sehingga MUI secara tegas menyatakan bahwa paham pluralisme agama bertentangan dengan ajaran Islam.

Menurut Azumardi Azra dalam penyusunan fatwa, MUI terutama dalam mendefinisikan istilah liberalisme dan pluralisme seharusnya tidak hanya sekedar mencari pertimbangan kajian fiqh, tetapi pertimbangan lain seperti pertimbangan sisi budaya, agama, dan lain-lain dalam konteks kebangsaan. Tetapi menurut hemat penulis terlepas tepat atau tidaknya definisi MUI tentang pluralisme agama sebagaimana di atas, justru pertimbangan tersebut telah memperhatikan aspek teologis, realitas, 
empiris dan sebagai tindakan preventif agar tidak terjadi pengikisan akidah umat terutama mereka yang memiliki taraf pemahaman agama yang masih rendah (MUI, 2011:1993).

\section{Makna Teks Ayat yang Berkaitan dengan Pluralitas Agama}

Dalam hasil penelitian Syamsul Hidayat, disebutkan bahwa para pemikir Islam berbeda pendapat dalam melihat isyarat-isyarat al-Quran tentang pluralisme keagamaan, pandangan pertama, dan ini merupakan pandangan yang dominan dalam Islam dan juga dalam agama-agama lain yaitu mereka yang berangkat dari klaim kebenaran atas agamanya sendiri, sementara agama orang lain adalah agama yang salah dan sesat. (Hidayat, 2001:93) Alasan yang memiliki pandangan yang pertama ini menurut hasil penelitian tersebut adalah bahwa isyarat al-Quran tentang pluralitas keagamaan dan adanya larangan pemaksaan dalam memasuki agama, adalah justru untuk menunjukan kebenaran Islam di atas agamaagama lain. Meski demikian Islam mengakui, bahkan menghormati kebenaran agama-agama tersebut. Beberapa ayat yang menjadi dasar rujukan pandangan pertama ini adalah al-Quran hanya memerintahkan mengajak mereka kepada akidah Islam dengan hikmah dan tanpa paksaan. Sekalipun orang-orang non muslim itu tetap kepada akidah mereka, hak-hak mereka dijamin oleh hukum syariah yang diterapkan secara sama sehingga seluruh warga bersama kedudukannya dihadapan hukum agama.

Menurut Roem Rowi yang dikutif Hidayat, tidak dipaksanya manusia untuk kembali bersatu dalam agama yang satu yakni Islam dikarenakan dua hal; Pertama, karena agama adalah keyakinan yang akan memberikan ketenangan dan kepuasan batin dan bahkan sebaliknya akan melahirkan sifat kemunafikan yang amat dibenci oleh Allah. Kedua, karena telah nyata jalan menuju kebenaran, sebagaimana jelasnya jalan menuju kesesatan, sementara manusia telah dilengkapi dengan perangkat 
akal. Barang siapa mencari agama selain Islam, maka sekali-kali tidak akan diterima agama itu darinya dan di akhirat termasuk orang-orang yang rugi (Hidayat, 2001:102).

Pandangan kedua kelompok pemikir di atas yang melihat bahwa isyarat al-Quran akan pluralisme keagamaan tersebut, tidak hanya menunjukan kebenaran Islam, selama esensi keberagamaan, yakni penyerahan diri secara total kepada Tuhan menjadi pandangan hidupnya. Dalam hal ini Ulil Absar Abdalla mengatakan semua agama sama, semuanya menuju jalan kebenaran. Dengan tanpa rasa sungkan dan kikuk, saya mengatakan semua agama adalah tepat berada pada jalan seperti itu, jalan panjang menuju yang maha besar (Abdalla, 2007:4). Semua agama dengan demikian adalah benar, dengan variasi tingkat dan kadar kedalaman yang berbeda-beda dalam menghayati jalan relegusitas itu. Semua agama ada dalam satu keluarga besar yang sama: yaitu keluarga pencinta jalan menuju kebenaran. Larangan kawin beda agama, dalam hal ini antara perempuan Islam dengan lelaki non muslim, sudah tidak relevan lagi. Amin Abdullah yang dikutif Hidayat menegaskan secara dialektis dan hermeneutika, al-Quran memberikan tawaran yang bersifat terapis dari kecendrungan umat beragama yang selalu ingin menuntut truth claim, secara sepihak (Hidayat, 2001:102).

Al-Quran memberikan jawaban yang sangat tegas terhadap pernyataan-pernyataan umat beragama yang bersifat ekslusif tersebut. Petunjuk bukanlah fungsi dari kaum-kaum tertentu, tetapi dari Allah dan manusia-manusia yang shaleh, tidak ada satu kaum pun dapat mengatakan atau mengklaim bahwa hanya merekalah yang telah diangkat Allah dan yang telah memperoleh petunjuk-petunjuk-Nya. Fazlur Rahman dalam bukunya Interpretion in the Quran yang dikutip oleh Alwi Shihab mengatakan bahwa ada beberapa ayat al-Quran yang menunjukan kepada nilai pluralisme Islam dan menjadi dasar argumentasi pandangan kedua ini antara lain adalah surat al-Hujarat ayat 13, Hai manusia sesungguhnya 
kami menciptakan kamu dari seorang laki-laki dan perempuan, dan menjadikan kamu berbangsa-bangsa dan bersuku-suku supaya kamu saling kenal mengenal. (Shihab, 1997:10) Sesungguhnya orang yang paling mulia diantara kamu disisi Allah ialah orang yang paling bertakwa diantara kamu. Sesungguhnya Allah maha mengetahui lagi maha mengenal. Ayat ini menjelaskan bahwa Allah SWT telah menciptakan makhluknya, lakilaki dan perempuan, dan menciptakan manusia berbangsa-bangsa, untuk menjalin hubungan yang baik. Kata ta'arafu pada ayat ini maksudnya bukan hanya berinteraksi tetapi berinteraksi positif, karena itu setiap hal yang baik dinamakan dengan ma'ruf. Jadi dijadikannya makhluk dengan berbangsa-bangsa dan bersuku-suku adalah dengan harapan bahwa satu dengan yang lainnya dapat berinteraksi secara baik dan positif.

Selanjutnya dalam Surat al-Ankabut ayat 46 Allah menegaskan dan janganlah kemu berdebat dengan Ahli Kitab, melainkan dengan cara yang paling baik, kecuali dengan orang-orang zalim di antara mereka, dan katakanlah, kami telah beriman kepada (kitab-kitab) yang diturunkan kepada kami dan yang diturunkan kepadamu, Tuhan kami dan tuhanmu adalah satu, dan kami hanya kepada-Nya berserah diri. Kemudian dalam surat al-Maidah 48 sekiranya Allah menghendaki, niscaya kamu dijadikannya satu umat saja, tetapi Allah hendak menguji kamu terhadap pemberian-Nya kepadamu, maka berlomba-lombalah berbuat kebajikan. Hanya kepada Allahlah kembali kamu semuanya, lalu diberitahukanNya kepadamu apa yang telah kamu perselisihkan itu. Pada ayat ini Allah menegaskan bahwa Dia dapat menciptakan suatu bangsa atau satu umat, tetapi kenapa tidak? Alasannya sebagaimana dijelaskan dalam lanjutan ayat, yaitu liyabluwakum fii ma atakum untuk menguji dengan apa yang kalian terima dari tuntunan Allah. Apakah manusia akan konsisten atau menyimpang. Oleh karena Allah ingin melihat siapa yang konsisten dan siapa yang menyimpang, maka fastabiqul khairat, berlomba-lombalah untuk menunaikan kebaikan. 
Jadi dengan demikian yang dikehendaki Allah adalah pluralisme interaksi positif, saling menghormati. Jikalau Tuhanmu menghendaki, tentu Dia menjadikan manusia umat yang satu, tetapi mereka senantiasa berselisih pendapat. Dalam ayat ini dapat dipahami kalau Tuhan mau, dengan gampang sekali akan menciptakan manusia semuanya dalam satu grup, monolitik dan satu agama, tetapi Allah tidak menghendaki hal tersebut. Tetapi justru Tuhan menunjukan kepada realita bahwa pada hakikatnya manusia itu berbeda. Ini kehendak Tuhan sebagaimana dalam al-Quran surat al-Baqarah ayat 62 sesungguhnya orang-orang Yahudi, orang-orang Nasrani dan Orang-orang Shabiin, siapa saja diantara mereka yang benar-benar beriman kepada Allah, hari kemudian serta beramal sholeh, mereka semua akan mendapat pahala dari Tuhan mereka dan tidak ada kuatir, tidak pula akan berselisih.

Jadi, jelasmenurutpandangankeduaini, bahwa nilai-nilaipluralismee dalam Islam dapat dijumpai dalam al-Quran. Hanya saja terkadang karena fanatisme manusia yang membawa dia bukan kepada khilaf, tetapi kepada syiqaq. Khilaf adalah perbedaan pendapat yang didasari atas saling hormat menghormati, sedangkan shiqâq adalah perbedaan pendapat yang membawa kepada pertikaian dan perselisihan. Menurut Quraish Shihab, kalaulah ayat ini dipahami oleh umat Islam sebagaimana bunyi harpiyahnya, dan diterima pula oleh para penganut agama lain, tanpa mengaitkan dengan teks-teks keagamaan yang lain niscaya absolutusme dalam keberagamaan niscaya akan berkurang dan akan pupus sama sekali. Sebagai ideologi dan gerakan politik, pluralitas pernah diteladani oleh Rasulullah SAW. Ketika Rasulullah Saw berada di Madinah. Apa yang diajarkan Nabi Muhammad SAW bukanlah upaya melegitimasi agama resmi saat itu dan bukan pula alat pemaksa agar orang-orang memeluk Islam seluruhnya. Dengan mengikuti prinsif universal keadilan ilahi saja, kita ketahui bersama bahwa perbedaan latar belakang pendidikan, lingkungan sosial, budaya dan kesempatan seseorang, meniscayakan diferensiasi penerimaan konsep tentang Tuhan dan Agama. 
Dalam hal toleransi Nabi Muhammad pernah memberikan suri teladan yang sangat inspiring dihadapan para pengikutnya. Sejarah mencatat bahwa Nabi pernah dikucilkan dan bahkan diusir dari tanah tumpah daranya (Makkah). Beliau terpaksa hijrah ke Madinah untuk beberapa lama dan kemudian kembali ke Makkah. Peristiwa ini dikenal dalam sejarah Islam fath ul-Makkah. Dalam peristiwa yang penuh kemenangan ini, Nabi tidak mengambil langkah balas dendam kepada siapapun juga yang telah mengusirnya dahulu dari tanah kelahiran kamu sekalian. Peristiwa ini sangat memberikan inspirasi dan memberikan kesan yang sangat mendalam terhadap penganut agama Islam dimanapun mereka berada dan Nabi telah memberikan contoh kongkrit dan sekaligus contoh pemahaman dan penghayatan pluralismee keagamaan yang amat riil dihadapan umatnya. Disini dimensi historisitas keteladanan Nabi menjadi sesuatu yang sangat penting dalam penghayatan beragama. Tanpa didahului polemik pergumulan filosofis-teologis, Nabi tidak menuntut truth claim atas nama dirinya maupun atas nama agama yang dianutnya. Dia mengambil sikap agree in disagreement. Dia tidak memaksakan agamanya untuk diterima oleh orang lain, tanpa kesadaran dari lubuk hatinya. Di situ nabi Muhammad SAW sangat mengakui eksistensi dan keberadaan agama-agama lain selain Islam.

Amin Abdullah berkomentar dalam perspektif Islam, dasar-dasar untuk hidup bersama dalam masyarakat yang pluralistik secara relegius, sejak semula memang telah dibangun diatas landasan normatif historis sekaligus. Jika ada hambatan atau anomala-anomali disana sini, penyebab utamanya bukan karena inti ajaran Islam itu sendri yang bersifat intoleran dan ekslusif, tetapi lebih banyak ditentukan dan dikondisikan oleh situasi historis-ekonomis-politis yang melingkari komunitas umat Islam di berbagai tempat. Kompetisi untuk menguasai sumber-sumber ekonomi, kekuasaan politik, hegemoni kekuasaan, jauh lebih mewarnai ketidakmesraan hubungan antar pemeluk agama dan bukannya oleh kandungan ajaran etika "agama" itu sendiri. (Abdullah, 1999:3) 


\section{Metode Penelitian}

Penelitian ini menggunakan jenis penelitian kualitatif. Penelitian kualitatif adalah penelitian yang menghasilkan data deskriptif berupa kata-kata tertulis atau dari lisan orang-orang atau perilaku yang dapat diamati. Pendekatan ini diarahkan pada latar dan individu secara holistik dan tidak menggunakan hipotesis (non hipotesis) sehingga dalam penelitian ini tidak perlu merumuskan hipotesis (Arikunto,1998:245). Peneliti menekankan untuk mengklarifikasi mengenai suatu fenomena yang terjadi atau kenyataan sosial dengan jalan mendekripsikan sejumlah variabel yang berkaitan dengan masalah dan unit yang diteliti.

Lokasi penelitian dilaksanakan di Randuacir Kecamatan Argomulyo Kota Salatiga Pertimbangan dalam pemilihan lokasi ini antara lain: (a) Desa Randuacir merupakan desa yang didalamnya dihuni oleh empat agama yaitu Islam, Kristen, Katolik dan Hindu. (b) Desa Randuacir merupakan desa yang berlokasikan dekat dengan tempat tinggal peneliti.

Data yang diperlukan untuk penelitian ini adalah data terkait dengan bagaimana pandangan masyarakat balun terhadap pluralismee dan bagaimana cara masyarakat Balun tetap menjalin kerukunan dalam satu lingkungan sosial. Untuk menggali kelengkapan data tersebut, maka diperlukan sumber data sebagai berikut: (a) Sumber Data Primer; subjek penelitian ynag dijadikan sebagai informasi penelitian dengan menggunakan alat pengukuran dan pengambilan data secara langsung atau yang dikenal dengan istilah wawancara atau interview dan melakukan observasi (Azwan, 2007:91). (b) Sumber Data Sekunder data yang diambil secara tidak langsung dari sumber data. Data sekunder dalam penelitian ini diperoleh melalui studi dokumentasi, data-data dari balai desa, internet, literatur-literatur dan dokumen-dokumen lainnya yang berhubungan dengan penelitian. 


\section{Pandangan Masyarakat tentang Nilai Pluralisme di Randuacir Argo- mulyo Salatiga}

Pandangan masyarakat Randuacir Argomulyo Salatiga melihat bahwa hubungan antarumat beragama selama ini ingin menjadikan agama sebagai dasar agar dalam kehidupan terjadi tentram, kerukunan. Dalam kehidupan beragama sekarang ini adalah bagaimana seorang beragama bisa mendefinisikan dirinya di tengah agama-agama lain. Secara garis besar pluralisme di masyarakat Randuacir menunjuk pada kenyataan tentang adanya kemajemukan, dan perlu adanya keterlibatan aktif dan interaksi positif terhadap kenyataan majemuk itu. Sebagian besar masyarakat Randuacir memahami tentang pluralisme bahwa tiap pemeluk agama dituntut bukan saja mengakui keberadaan dan hak agama lain, tapi terlibat dalam usaha memahami perbedaan dan persamaan guna tercapainya kerukunan dalam kebhinekaan.

Masyarakat Randuacir dihadapkan untuk mengambil sikap di tengah-tengah masyarakat pluralis, bagaimana pluralisme memacu agama-agama memberi arti penting bagi kehidupan dan menjadi jalan bagi manusia untuk mencapai kedamaian, menemukan bahasa pemersatu yang mampu menyelaraskan hubungan antaragama. Sikap pluralis semakin diperhatikan dan diterima banyak pemikir dan tokoh agama, meskipun dalam pengertian yang berbeda-beda.

Banyak tokoh agama randuacir bahwa tantangan yang dihadapi bukan bagaimana menyelamatkan agama dari keaneragaman teologi, misi, dan tradisi, melainkan bagaimana membangun komitmen menghargai perbedaan itu. Al-Quran sendiri hanya menganjurkan agar kita mencari-cari titik temu ataun kalimatun sawa, bukan menyeragamkan perbedaan dalam teologi, ritual atau institusi, sebab keragaman itu memang desain Illahi

Dalam konteks masyarakat pluralistik, maka syariah harus mampu mengakomodir kepentingan-kepentingan kaum minoritas sebagai bagian dari hak-hak dasar yang harus diakuinya. Bukan saja pada kelompok 
mayoritas yakni Islam tetapi sekaligus menempatkan kaum minoritas bukan sebagai second human, yang derajatnya di bawah kaum muslimin. Identifikasi problem masyarakat agama dalam realitas pluralisme agama yang ada di Randuacir harus dilakukan secara terbuka, sehingga di antara mereka saling memahami apa yang menjadi harapan dan ketakutan dalam bermasyarakat.

Dengan hadirnya agama-agama dan menerima pluralisme, maka akan lahir toleransi dalam kehiupan beragama. Toleransi sendiri merupakan salah satu unsur budaya demokrasi yang diyakini merupakan faktor menentukan bagi tercitanya konsolidasi demokrasi. Tidak ada perdamaian dunia tanpa perdamaian agama. Tidak ada perdamaian agama tanpa perdamaian dunia. Hidup dalam realitas pluralitas yang merupakan sunatullah, sekaligus menjadi way of life, dari sinilah demokrasi dalam kehidupan beragama akan tumbuh.

\section{Pola Kerukunan Antarumat Beragama di Randuacir Argomulyo Salatiga}

Kerukunan sebagai bagian dari kebutuhan individu atau kelompok dalam menata kehidupan bermasyarakat, yang mendorong sikap dan perilaku mereka dalam mewujudkan kehidupan bersama secara harmonis dan rukun.

Pola kerukunan umat beraga yang ditunjukkan oleh masyarakat Desa Randuacir Kecamatan Argomulyo Kota Salatiga tentang sikap dan perilaku individu atau kelompok di dalam rona pergaulan mereka di keluarga dan kerabat, lingkungan tempat tinggal serta tempat kerja mereka. Berkaitan pola-pola umum kerukunan itu, masyarakat Desa Randuacir yang memiliki citra sebagai desa yang plural. Masyarakat Desa Randuacir di dalam komunitas yang memiliki citra homogen, warganya sangat toleran terhadap variasi sosial dan pluralitas yang berkembang di dalam kehidupan sosialnya. Dalam hal ini, citra homogenitas tersebut 
mengacu pada menonjolnya bentuk-bentuk aktivitas dan kelembagaan sosial yang dominan dalam komunitas tersebut sehingga homogen tidaklah berarti keseragaman, melainkan kesan umum yang tampak menjadi karakteristik sosialnya. Berkenaan dengan pengertian tersebut, masyarakat Desa Randuacir ini menegaskan bahwa citra komunitas yang homogen itu juga memiliki variasi dan segmentasi sosial yang majemuk sebagai konsekuensi pertumbuhan kota.

Masyarakat Desa Randuacir memperlihatkan bahwa dalam komunitas ini, orang bisa menerima perbedaan dan pluralitas masyarakatnya sekali pun mereka berasal dari kelompok-kelompok yang dominan. Di dalam keluarga dan lingkungan kerabat, sikap toleran tersebut ditunjukkan dengan penerimaan terhadap anggotanya melalui perkawinan. Orang bisa menerima anggota keluarganya yang kawin dengan suku atau dari kelompok etnis lain. Orang yang beragama lain masih bisa diterima melalui perkawinan campur, walaupun kalau bisa dicegah atau dihindarkan. Akan tetapi, mereka cenderung keberatan dengan kepindahan anggotanya menjadi pemeluk agama lain. Dalam konteks ini, tampaknya persoalan lebih disebabkan pada gagasan tentang keluarga yang tunggal dan usaha menjaga reputasi orang tua serta kerabat dalam hal mendidik anggotanya untuk patuh.

Namun demikian, perbedaan afiliasi anggota keluarga terhadap partai politik bisa dimaklumi. Di dalam lingkungan tempat tinggal, perbedaan dan multikulturalisme diterima warga masyarakatnya dalam hubungan ketetanggaan. Mereka menunjukkan kepedulian dan bahkan rasa kesetiakawanan sebagai warga kampung satu dengan yang lainnya. Partisipasi sebagai warga tampak cukup tinggi dalam merembug kepentingan bersama di wilayahnya atau memecahkan persoalan-persoalan di sekitarnya, seperti kebersihan lingkungan, keamanan dan bahkan kesejahteraan sosial dengan menyantuni tetangga yang kurang beruntung secara ekonomis. Di dalam komunitas kampung, partisipasi warga terhadap 
aktivitas tampaknya tinggi pada tingkat RT dan semakin berkurang pada tingkat di atasnya, yaitu RW dan Kelurahan. Hal ini dimungkinkan oleh pergaulan yang lebih intensif di RT ketimbang pada tingkat RW dan Kelurahan yang lebih merupakan kepanjangan tangan birokrasi negara.

Sementara itu, di lingkungan pekerjaan yang lebih plural latar belakang sosio kulturalnya, orang bisa bersikap toleran dengan keanekaragaman tersebut. Hal ini berkaitan dengan hubungan fungsional yang terjalin di sektor pekerjaan karena suasana kondusif dalam bekerja menjadi kepentingan bersama. Hal-hal yang cenderung dihindarkan di lingkungan pekerjaan secara umum menyangkut intervensi terlalu dalam terhadap persoalan yang dianggap sensitif dalam hubungan tersebut. Sikap dan perilaku toleran tersebut misalnya orang cenderung ikut berpartisipasi dalam pembangunan fasilitas agama lain, tetapi tidak ikut terlibat secara aktif kegiatan agama bersangkutan meski terbuka kemungkinan menghadirinya. Sekalipun demikian, batas-batas toleransi terjadi berkenaan dengan masalah ideologi dan kepercayaan.

Masyarakat Randuacir cenderung membatasi keterlibatan orang lain dalam kehidupan pribadinya atau di dalam memperbincangkan agama, kepercayaan atau afliasi politiknya. Dalam hal ini, persoalan yang berkaitan dengan keluarga cenderung diselesaikan secara internal dalam keluarga dan kerabatnya. Lebih dari itu, orang bisa menerima bahkan secara leluasa bebas mengutarakan persoalan-persoalan sosial lainnya, seperti hubungan ketetanggaan, pekerjaan, kegemaran dan hobi.

\section{Simpulan}

Dalam penelitian ini disimpulkan bahwa pandangan masyarakat randuacir tentang pluralisme diterimanya pancasila sebagai dasar negara dan ideologi beraga membawa konsekuensi logis bahwa nilai-nilai Pancasila dijadikan landasan pokok, landasan bagi penyelenggaraan negara Indonesia. Makna nilai ketuhanan pada sila pertama Pancasila 
juga memiliki arti adanya pengakuan akan kebebasan memeluk agama, menghormati kemerdekaan beragama, serta tidak berlaku diskriminatif antar umat beragama. Membumikan Pancasila berarti menjadikan nilainilai Pancasila menjadi nilai-nilai yang hidup dan diimplementasikan dalam kehidupan sehari-hari. Internalisasi nilai-nilai Pancasila bisa juga melalui pendidikan formal maupun nonformal (masyarakat). Pada tataran pendidikan formal, perlu revitalisasi mata pelajaran pendidikan kewarganegaraan, termasuk juga pendidikan agama.

Pola toleransi yang ditunjukkan oleh masyarakat Desa Randuacir Kecamatan Argomulyo Kota Salatiga mengenai sikap dan perilaku individu atau kelompok di dalam pergaulan mereka dikeluarga dan kerabat, lingkungan tempat tinggal serta tempat kerja mereka. Masyarakat Desa Randuacir di dalam komunitas yang memiliki citra homogen, warganya sangat toleran terhadap variasi sosial dan pluralitas yang berkembang di dalam kehidupannya. Berkenaan dengan itu, masyarakat Desa Randuacir ini menegaskan bahwa citra komunitas yang homogen itu juga memiliki variasi dan segmentasi sosial yang majemuk sebagai konsekuensi pola hubungan bermasyarakat, dan memperlihatkan bahwa dalam komunitas, orang bisa menerima perbedaan dan pluralitas masyarakatnya sekali pun mereka berasal dari kelompok-kelompok yang dominan

Bentuk kerukunan umat beragama di Randuacir Kecamatan Argomulyo Kota Salatiga; (1) kerukunan antar pemeluk agama yang sama, yaitu suatu bentuk kerukunan yang terjalin antar masyarakat penganut satu agama. Misalnya, kerukunan sesama orang Islam atau kerukunan sesama penganut Kristen. (2) kerukunan antar umat beragama lain, yaitu suatu bentuk kerukunan yang terjalin antar masyarakat yang memeluk agama berbeda-beda. Misalnya, kerukunan antar umat Islam dan Kristen, antara pemeluk agama Kristen dan Budha, atau kerukunan yang dilakukan oleh semua agama. (3) menjunjung tinggi rasa toleransi antar umat beragama, baik sesama antar pemeluk agama yang sama maupun 
yang berbeda. Rasa toleransi bisa berbentuk dalam macam-macam hal. Misal, perijinan pembangunan tempat ibadah oleh pemerintah, tidak saling mengejek dan mengganggu umat lain, atau memberi waktu pada umat lain untuk beribadah bila memang sudah waktunya. Banyak hal yang bisa dilakukan untuk menunjukkan sikap toleransi. Hal ini sangat penting demi menjaga tali kerukunan umat beragama di Randuacir. (4) saling membantu sesama dan tidak melakukan diskriminasi terhadap suatu agama, terutama saat mereka membutuhkan bantuan. Misalnya, di suatu daerah di Indonesia mengalami bencana alam. Mayoritas penduduknya adalah pemeluk agama Kristen. (5) selalu jaga rasa hormat pada orang lain tanpa memandang agama apa yang mereka anut. Misalnya dengan selalu berbicara halus dan tidak sinis. Hal ini tentu akan mempererat kerukunan umat beragama di Indonesia. (6) bila terjadi masalah yang menyangkut agama, tetap selesaikan dengan kepala dingin tanpa harus saling menyalahkan. Para pemuka agama, tokoh masyarakat, dan pemerintah sangat diperlukan peranannya dalam pencapaian solusi yang baik dan tidak merugikan pihak manapun, atau mungkin malah menguntungkan semua pihak.

\section{Daftar Pustaka}

A'la, Abd. dkk. 2005. Nilai-nilai Pluralisme dalam Islam. Bandung: Pustaka Nuansa. Bandung.

Abdullah, M. Amin. 1999. Studi Agama: Normativitas atau Historisitas. Yogyakarta: Pustaka Pelajar.

Barton, Greg. 1999. Gagasan Islam Liberal Di Indonesia Pemikiran Neomodernisme Nurchalis Madjid, Djohan Efendi, Ahmad wahib dan Abdurrahman Wahid. Jakarta: Paramadina, Yayasan Adikarya Ikapi, dan Ford Foundation.

Biyanto. 2009. Pluralisme Keagamaan dalam Perdebatan, Pandangan Kaum Muda Muhammadiyah. Malang: UMM. 
Fakhruddin, Fuad. 2012. "Korelasi antara Kesadaran Plurlisme Agama dengan Perilaku Sosial Siswa Muslim SMP Negeri 4 Salatiga Tahun Ajaran 2011/2012". Skripsi. Salatiga: STAIN Salatiga.

Hadar, M. Nawawi dan Martini Hadari. 1995. Instrument Penelitian Bidang Sosial. Yogyakarta: Gajah Mada University.

Hakim, Abdul. Jaih Mubarak. 2000. Metodologi Studi Islam. Bandung: Remaja Rosda Karya.

Hakim, Abdul. Dkk. 2000. Metodologi Studi Islam. Bandung: Remaja Rosda Karya.

Helim, Abdul (ed.). 2001. Teologi Islam Rasional, Apresiasi Terhadap Wacana dan Praksis Harun Nasution. Jakarta: Ciputat Pers.

Hidayat, Syamsul. 2001. Studi Agama dalam Pandangan Al-Qur'an. Penelitian. Husaen, Muhammad. 2011. Mengaji Pluralisme. Bandung: Putaka Nuansa. Husaini, Usman. 1996. Metodologi Penelitian Sosial. Jakarta: Bumi Aksara. Imarah, Muhammad. 1999. Islam dan Pluralitas: Perbedaandan Kemajemukan dalam Bingkai Persatuan. Jakarta: Gema Insani Press.

Ismail, H. Faisal. 2002. Pijar-Pijar Islam: Pergumulan Kultur dan Struktur, Jakarta: Balitbang Agama dan Diklat Keagamaan Depag RI.

Jannah, Fadhulil. 2014. "Model Toleransi Keagamaan Remaja Muslim Pada Lingkungan Beda Agama di Dusun Celengan Desa Lopait Kecamatan Tuntang Kabupaten Semarang Tahun 2014" Skripsi. Salatiga: STAIN Salatiga.

Kahmad, H. Dadang. 2002. Sosiologi Agama. Bandung: Remaja Rosdakarya. Kuntowijoyo. 1994. Paradigma Islam Interpretasi Untuk Aksi. Bandung: Mizan. Madjid, Nurchalish. 2004. Islam Doktrin dan Peradaban: Sebuah Telaah Kritis Tentang Masalah Keimanan, Kemanusiaan dan Kemoderenan. Jakarta: Paramadina.

Majelis Ulama Indonesia. 2011. Himpunan Fatwa MUI Sejak 1975. Jakarta: MUI dan Penerbit Erlangga.

Mansur. 2004. Peradaban Islam Dalam Lintasan Sejarah. Yogyakarta: Global Pustaka Utama. 
INJECT: Interdisciplinary Journal of Communication, Vol.1, No.1, Juni 2016: h. 99-118

Moleong, L. 1997. Metodologi Penelitian Kualitatif. Bandung: Remaja Rosda Karya.

Munawaroh, Jauharotul. 2012. "Konsep Pluralisme Agama dan Implikasinya dalam Pendidikan Islam Studi Analisis Pemikiran KH. Abdurrahman Wahid". Skripsi. Semarang: IAIN Walisongo Semarang.

Nata, Abuddin. 1998. Metodologi Studi Islam. Jakarta: Raja Grafindo Persada.

Pius A. P \& M. Dahlan. 1994. Kamus Ilmiah Popular. Surabaya: Arkola. Nasution, S. 1996. Metode Research. Bandung: Bumi Aksara.

Saifuddin. 2000. "Upaya Mempertemukan Realitas Dalam Pluralitas Sosial Budaya". Jurnal Suhuf. No. 01 Tahun XII.

Shihab Alwi. 1997. Islam Inklusif: Menuju Sikap Terbuka Dalam Beragama. Jakarta: Mizan.

Shihab, M. Quraish. 1999. Membumikan Al-Qur'an. Bandung: Mizan. 1998. Wawasan Al-Qur'an. Bandung: Mizan.

Shihab, Umar. 2004. Kontekstualitas Al-Qur'an, Kajian Tematik Atas AyatAyat Hukum Dalam Al-Qur'an, Jakarta: Pena Madani.

Sifuddin Azwan. 2007. Metode Penelitian. Yogyakarta: Pustaka Belajar.

Sudjana, Nana. 2003. Tuntunan Penyusunan Karya Ilmiyah: Makalah-

Skripsi-Tesis- Disertasi. Bandung: Sinar Baru Algesindo.

Sugiyono. 2010. Metode Penelitian Kuantitatif, Kualitatif dan R\&D. Bandung: Alfabeta.

Arikunto, Suharsimi. 1998. Prosedur Penelitian Suatu Pendekatan Praktek. Jakarta: Rineka Cipta.

Sururin (ed.). 2005. Nilai-Nilai Pluralisme Dalam Islam: Bingkai Gagasan yang Berserak. Bandung: Nuansa.

Ma'arif, Ahmad Syafi'i. 1985. Al Qur'an, Realitas Sosial dan Lombo Sejarah. Bandung: Pustaka.

Thoha, Anis Malik. 2005. Tren Pluralismee Agama, Tinjauan Kritis. Jakarta: Perspektif. 